\title{
Fizikalno-kemijska svojstva soka različitih sorti jabuka
}

\author{
Physico chemical properties of juice of different apple varieties
}

\author{
Sandra Voća, Jana Šic Žlabur, Martina Skendrović Babojelić, M. Boić, A. Galić
}

\section{SAŽETAK}

Cilj rada bio je analizirati i usporediti nutritivnu kvalitetu mutnih, svježe cijeđenih sokova iz plodova četiriju različitih sorti jabuka: 'Idared', 'Jonagold', 'Golden Delicious' i 'Cripps Pink'. S obzirom na analizirani mehanički sastav utvrđeno je da najbolje iskorištenje ploda za dobivanje soka ima sorta 'Idared' (45,51\%), zatim slijedi sorta 'Golden Delicious (44,22\%), 'Jonaglod' (36,56\%) te sorta 'Cripps Pink' (25,75\%). Prema rezultatima dobivenim u ovom istraživanju sok sorte 'Golden Delicious' pokazuje najveći omjer TST/UK, zatim sok sorte 'Jonagold', 'Idared', dok je najmanji omjer utvrđen kod soka sorte 'Cripps Pink'. Najveći sadržaj vitamina C (6,75 mg/100g svježeg ploda) kao i najveći sadržaj ukupnih fenola (55,84 mgGAE/100 g svježe tvari) utvrđeni su u soku sorte 'Jonagold' Temeljem dobivenih rezultata može se zaključiti da su plodovi svih istraživanih sorti pogodni za proizvodnju mutnog soka, ali i da mogu biti dobra podloga za proizvodnju ostalih sokova od raznih vrsta voća.

Ključne riječi: mutni sok, mehanički sastav, kemijski sastav, ukupni fenoli, vitamin C

\section{ABSTRACT}

The aim of the study was to analyse and compare the nutritional quality of cloudy, freshly squeezed fruit juices from four different apple cultivars: 'Idared', 'Jonagold', 'Golden Delicious' and 'Cripps Pink'. Considering the analysed mechanical composition, it was determined that the best yield of fruit for juice production has the cultivar 'Idared' (45.51\%), followed by the cultivar 'Golden Delicious' $(44.22 \%)$, 'Jonaglod' (36.56\%) and the 'Cripps Pink' cultivar (25.75\%). According to the results obtained in this study, the juice of the 'Golden Delicious' cultivar shows the highest TST/UK ratio, followed by the juice of the 'Jonagold' and 'Idared' cultivars, while the lowest ratio was found for the juice of the 'Cripps Pink' cultivar. The highest content of vitamin $\mathrm{C}$ was determined in the juice of the cultivar 'Jonagold' $(6.75 \mathrm{mg} / 100 \mathrm{~g}$ of fresh fruit) as well as the highest content of total phenols (55.84 mg GAE/100 $\mathrm{g}$ of fresh matter). Based on the obtained results, it can be concluded that the fruits of all investigated cultivars are suitable for the production of cloudy juice, but also that they can be a good base for the production of juices from various types of fruit.

Key words: cloudy juice, mechanical composition, chemical composition, total phenols, vitamin $\mathrm{C}$ 


\section{UVOD}

Mutni sok od jabuke zbog značajnog sadržaja različitih nutrijenata poput ugljikohidrata, posebno fruktoze i glukoze, opskrbljuje organizam energijom te pokazuje i pozitivan utjecaj na zdravlje; pridonosi sprječavanju umora i gubitku koncentracije (Gliszczynska-Swiglo i sur., 2003.; Faria i sur, 2017.). Osim navedenih makronutrijenata, sok od jabuke bogat je izvor i različitih bioaktivnih spojeva poput askorbinske kiseline, polifenola i pektina (Oszmianski i sur, 2007.; Fonteles i Rodrigues, 2018.), čime njegova konzumacija pokazuje dobrobit za ljudsko zdravlje (Kaur i Kapoor, 2001.; Gliszczynska-Swiglo i sur., 2003.; Fonteles i Rodrigues, 2018.).

Osim navedenog, s potrošačkog aspekta, vrlo je važna i harmoničnost okusa nekog proizvoda (soka) na što direktan utjecaj imaju parametri kemijskog sastava, i to: sadržaj topljive suhe tvari i sadržaj ukupnih kiselina (Hui i sur., 2006.; Fonteles i Rodrigues, 2018.). S obzirom na sve navedeno, u konzumiranju naglasak se daje proizvodima s očuvanim nutritivnim kvalitetama prihvatljivih organoleptičkih svojstava. Mutni sok karakterističan je proizvod zbog mutnoće, posljedice prisutnosti pektina i ostalih koloidnih čestica koje se tijekom proizvodnje ne talože i u konačnici bistre. Upravo zbog navedenog, mutni sok često sadrži veći sadržaj nutrijenata poput vitamina, minerala i ostalih bioaktivnih spojeva $u$ odnosu na bistri sok, te iz tog razloga ima i veću zdravstvenu vrijednost, no ipak potrošači ga rjeđe koriste, u većini slučajeva zbog njegovog izgleda (opalescentnosti) kojim najčešće stječu dojam da je bistri sok higijenski prihvatljiviji od mutnog (Kaur i Kapoor, 2001.; Rodrigues i sur. 2017.). Postupak proizvodnje soka od voća prešanjem i pasterizacijom omogućava najbolje očuvanje korisnih tvari (vitamina, minerala, enzima). Proizvedeni sok za razliku od sokova proizvedenih iz koncentrata, sastoji se od stopostotnog sadržaja voća, te ne sadrži dodanu vodu, konzervanse ni aditive (Kotar i sur., 2009). Za proizvodnju soka koriste se različite sorte jabuka u fazi tehnološke zrelosti. Prednost je ta što je moguće korištenje i onih plodova koji zbog veličine ili izgleda (vanjskog oštećenja ploda izazvanog tučom i sl.) nije moguće prodati u svježem stanju kao konzumnu robu. Na taj se način može iskoristiti voće, tzv. industrijske kvalitete, koje zbog tehnoloških pogrešaka i vremenskih uvjeta uvijek ima u manjoj ili većoj količini. Proizvodnja sokova iz svježih plodova naročito je prikladna za voće čiji su plodovi tvrđe konzistencije, jer se zbog velikih sila prešanja postiže dobra iskoristivost, od 65 pa čak do $80 \%$. Tako je na primjer za proizvodnju jedne litre soka od jabuke potrebna količina od 1,25 do $1,5 \mathrm{~kg}$ plodova jabuka (Kotar i sur. 2009.). 
Temeljem svega navedenog, cilj ovog rada bio je analizirati i usporediti kvalitetu mutnih svježe cijeđenih sokova četiriju sorti jabuka: 'Idared', 'Golden Delicious', 'Jonagold', 'Cripps Pink'.

\section{MATERIJALI I METODE}

Biljni materijal

Plodovi sorti: 'Idared', 'Golden Delicious', 'Jonagold' i 'Cripps Pink' ubrani su u nasadu jabuka pokraj Požege. Sorte 'Golden Delicious' i 'Jonagold' ubrane su početkom rujna, 'Idared' početkom listopada, a sorta 'Cripps Pink' ubrana je početkom studenog, $u$ stadiju optimalne zrelosti. Ubrani plodovi navedenih sorti čuvani su u skladištu od berbe do početka veljače, prilikom čega je temperatura skladištenja iznosila $5{ }^{\circ} \mathrm{C}$, a relativna vlaga zraka $80 \%$. Plodovi su u kartonskoj ambalaži dopremljeni do laboratorija Zavoda za tehnologiju na Agronomskom fakultetu u Zagrebu gdje je proizveden sok od jabuke iz mesnih polutki s kožicom procesom istiskivanja soka na centrifugalnom sokovniku (Bullet Express, Njemačka).

Prije početka eksperimentalnih analiza plodovi jabuka su oprani u sanitarno ispravnoj vodi i poslije pranja prosušeni. Nakon pranja i prosušivanja plodovi su izvagani za potrebe određivanja mehaničkog sastava. Od svake sorte za daljnje analize koristilo se u prosjeku 56 plodova.

Priprema svježeg, mutnog soka od jabuke

Nakon vaganja plodovima su uklonjena oštećenja, trulež i sjemena loža s peteljkom, a preostale mesne polutke s kožicom izrezane su na kriške. Kriške plodova jabuka su izvagane i označene kao mesne polutke (upotrebljivi dio), a sav uklonjeni dio ploda jabuke (trulež, sjemena loža s peteljkom), također su izvagani i označeni kao otpad (neupotrebljivi dio). Iz mesnih polutki s kožicom procesom istiskivanja soka na centrifugalnom sokovniku Bullet Express (Njemačka) dobiven je mutni sok za svaku pojedinu sortu. Volumen dobivenog soka za svaku sortu izmjeren je u litrama, a masa preostale mesne pulpe je izvagana na tehničkoj vagi (Mettler-Toledo, Švicarska). Sok je rastočen u plastične boce, te čuvan u hladnjaku pri temperaturi od $7-8{ }^{\circ} \mathrm{C}$ za potrebe provedbe kemijskih analiza. 
Kemijske analize nutritivne kvalitete soka

Za potrebe određivanja nutritivne kvalitete sokova provedene su sljedeće kemijske analize: određivanje sadržaja ukupne suhe tvari u soku (piknometrijski), gustoća soka $\left(\mathrm{g} / \mathrm{cm}^{3}\right)$ digitalnim denziometrom (Mettler Toledo, Densito 30PX, Švicarska=), pH-vrijednosti soka digitalnim pH-metrom (Mettler-toledo, Switzerland), sadržaja ukupnih kiselina u soku potenciometrijskom titracijom, sadržaja topljive suhe tvari digitalnim refraktometrom (Mettler Toledo, Refracto 30PX, Švicarska) temeljem standardnih laboratorijskih analiza (AOAC,1995), sadržaj prirodnog i ukupnog inverta te saharoze određen je metodom po Loof-Schoorlu; određivanje sadržaja vitamina $\mathrm{C}$ titrimetrijski s 2,6-p-diklorindofenolom (AOAC, 2002) te ukupnih fenola spektrofotometrijski (Shimadzu UV 1650, Japan) pri valnoj duljini 750 $\mathrm{nm}$ uz destiliranu vodu kao slijepu probu, temeljem kolorimetrijske reakcije $\mathrm{s}$ Folin-Ciocalteu reagensom (Ough i Amerine, 1988.).

Svi podaci u radu su statistički obrađeni u programskom sustavu SAS, verzija 9.3 (SAS, 2010.), te su prikazani u grafikonu i tablicama. Rezultati su podvrgnuti jednosmjernoj analizi varijance (ANOVA). Korišten je Duncanov test značajnosti razlika (1\%). Sve laboratorijske analize rađene su u tri repeticije. Srednje vrijednosti uspoređene su t-testom (LSD). U grafikonima su prikazane srednje vrijednosti obrađenih podataka.

\section{REZULTATI I RASPRAVA}

Analizirana je masa uzoraka (56 plodova) svake pojedine sorte. Od svih analiziranih sorti jabuka najveću prosječnu masu uzorka (56 plodova) imala je sorta 'Golden Delicious' (9,95 kg), zatim 'Cripps Pink' (9,71 kg), 'Jonagold' (9,3 $\mathrm{kg})$, dok je najmanja masa uzorka utvrđena kod sorte 'Idared' $(9,25 \mathrm{~kg})$ (Grafikon 1). Usporedi li se dobiveni volumen soka za svaku analiziranu sortu, može se zaključiti da su uzorci sorte 'Golden Delicious'dali najveći volumen soka (4,4 L), zatim slijede 'Idared' (4,1 L), 'Jonagold' (3,4 L) i na posljednjem mjestu je sorta 'Cripps Pink' (2,5 L). Razlog tako velikom odstupanju u dobivenom volumenu soka između analiziranih sorti je u tome što sorte 'Idared', 'Jonagold' i 'Golden Delicious' imaju relativno krupne plodove u odnosu na plodove sorte 'Cripps Pink'. Sorta 'Cripps Pink' u odnosu na ostale tri analizirane sorte ima i manji postotak vode i tvrđu teksturu mesa pa je iz tog razloga dala manju količinu soka. 'Cripps Pink' nije pogodna za preradu već se u najvećoj mjeri koristi kao konzumna (stolna) jabuka (Krpina i sur., 2004.). 


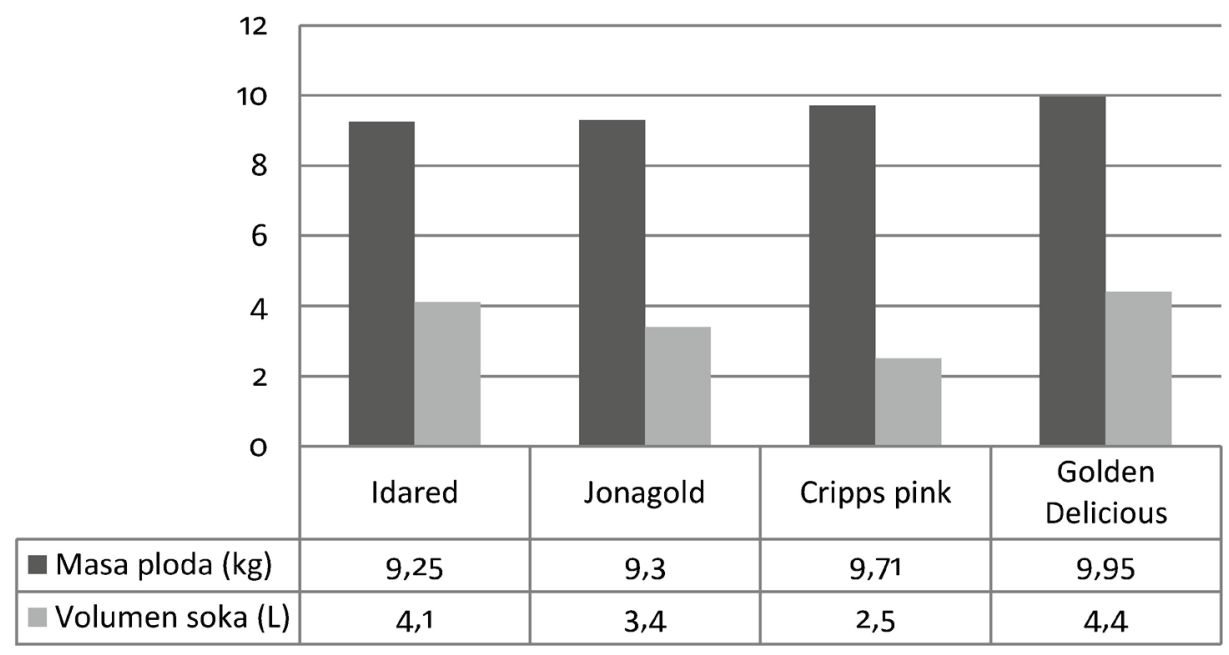

Grafikon 1. Masa plodova svake pojedine istraživane sorte $(\mathrm{kg})$ i volumena dobivenog prirodnog mutnog soka od jabuka (L)

Graph 1 Fruit weight of each individual investigated variety $(\mathrm{kg})$ and volume of obtained natural cloudy apple juice $(L)$

Iskoristivost plodova za dobivanje soka jedan je od prvih pokazatelja je li neka sorta pogodna za preradu u sok. U ovom istraživanju najveći postotak iskoristivosti ploda za dobivanje prirodnog soka utvrđen je za plodove sorte 'Idared' (44,31\%), zatim slijede plodovi sorte 'Golden Delicious' $(44,21 \%)$, 'Jonagold' (36,55\%) dok je najmanje iskorištenje plodova utvrđeno kod sorte 'Cripps Pink' $(25,74 \%)$. Dobiveni rezultati iskoristivosti plodova istraživanih sorti za dobivanje mutnog soka u skladu su s literaturnim navodima. Naime, sorte 'Idared', 'Golden Delicious'i 'Jonagold' izrazito su pogodne za preradu u sok ponajviše iz razloga što navedene sorte karakterizira visok postotak vode $u$ plodu, te se i preporučuju u tehnologijskim procesima prerade kao sorte izrazito pogodne za oblike procesiranja poput dobivanja prirodnog soka postupcima prešanja (Miljković, 1991.). 
Sandra Voća i sur.: Fizikalno-kemijska svojstva soka različitih sorti jabuka

Tablica 1. Osnovni kemijski sastav sokova različitih sorti jabuka

Table 1 Basic chemical composition of juices of different varieties of apples

\begin{tabular}{|c|c|c|c|c|c|}
\hline Uzor & ST (\%) & TST & UK_F & pH & Gustoća $\left(\mathrm{g} / \mathrm{cm}^{3}\right)$ \\
\hline & $P-0$ & & & & \\
\hline $\mathrm{S} 1$ & 18,18 & 17 & 24 & $4,04 c$ & 01 \\
\hline S2 & 9,01 & 13,70 & 0,4 & $355 \mathrm{ct}$ &, 01 \\
\hline $\mathrm{S} 3$ & $64 d \pm 0,01$ & 23 & $G$ & 5 & 1 \\
\hline S4 & $18,98 \mathrm{~b} \pm 0,01$ & $13,53 \mathrm{~b} \pm 0,12$ & $0,33 \mathrm{~b} \pm 0,01$ & $3,93 \mathrm{~b} \pm 0,006$ & $13,43 a \pm 0,01$ \\
\hline
\end{tabular}

S1- sok sorte 'Golden Delicious'; S2- sok sorte 'Idared'; S3- sok sorte 'Cripps Pink'; S4 - sok sorte 'Jonagold'; ST- sadržaj ukupne suhe tvari; TST- sadržaj topljive suhe tvari; UK_KIS- sadržaj ukupnih kiselina. Prikazane su prosječne vrijednosti \pm SD (standardna devijacija). Različita slova pridodana prosječnim vrijednostima označuju da se sorte statistički značajno razlikuju u istraživanom svojstvu prema $\mathrm{p} \leq 0,0001$.

Iz Tablice 1 vidljivo je da sokovi svih četiriju istraživanih sorti plodova jabuka imaju približno isti postotak ukupne suhe tvari (ST). Najveću ST imala je sorta 'Idared' (19,01\%), zatim sorta 'Golden Delicious' (18,18\%), 'Jonagold' (18,98\%), a najmanji postotak utvrđen je u soku sorte 'Cripps Pink' $(17,64 \%)$. Uspoređujući rezultate drugih autora može se zaključiti da su vrijednosti ST približno jednake podacima dobivenim u ovom istraživanju. Drugi autori navode podatke prosječne vrijednosti za suhu tvar soka jabuke od 13,80\% (Niketić-Aleksić, 1988.) te 12,20 do 14,20\% (Brajanoski i Brajanoski, 2004.). Najveći sadržaj topljive suhe tvari (TST) izmjeren je u soku sorte 'Cripps Pink' $(15,23 \%)$, zatim u soku sorte 'Idared' i 'Jonagold' (13,70\% i 13,53\%), dok sok sorte 'Golden Delicious' ima najmanju TST vrijednost (12,17\%) (Tablica 1). Prema Laimburgu (SI) preporučene vrijednosti sadržaja topljive suhe tvari za sortu 'Idared' iznose 10,5 - 11,5, za sortu 'Jonagold' 12 - 13,5, za 'Cripps Pink' 13,5 - 14,5, a za 'Golden Delicious' 11,5 do 13,0. Uspoređujući dobivene rezultate $u$ istraživanju i preporučene vrijednosti šećera za ocjenu zrelosti ploda jabuke koje se koriste u preradi može se zaključiti da je sorta 'Golden Delicious' u skladu s preporučenim vrijednostima topljive suhe tvari, a sorte 'Idared', 'Jonagold' i 'Cripps Pink' neznatno odstupaju od preporučenih vrijednosti. TST uzoraka sokova različitih sorata jabuka analiziranih $\mathrm{u}$ ovom istraživanju prosječne je vrijednosti od $13,66 \%$ što je u skladu i s drugim literaturnim navodima za sok jabuke (Eisele i Drake, 2005.; Suárez i sur., 2011.). Omjer topljive suhe tvari i ukupnih kiselina (TST/UK) važan je u definiranju harmoničnosti okusa, a oba su faktora (sadržaj topljive suhe tvari i ukupnih kiselina) u najvećoj mjeri pod utjecajem procesa zrenja ploda. Naime, plodovi u stadiju tehnološke zrelosti postižu najbolji (najveći) omjer TST/UK, a što je 
omjer veći to je kvaliteta ploda i proizvoda poput soka bolja (Katalinić, 2006.). Prema rezultatima dobivenim u ovom istraživanju sok sorte 'Golden Delicious' pokazuje najveći omjer TST/UK, zatim sok sorte 'Jonagold', 'Idared', dok je najmanji omjer utvrđen kod soka sorte 'Cripps Pink'. Uspoređujući rezultate sokova svih sorti vidljivo je da 'Golden Delicious' i 'Jonagold' imaju najveći omjer TST/UK, odnosno sokovi navedenih sorti pokazuju najbolju harmoničnost okusa što je i očekivano s obzirom na to da su spomenute sorte izrazitih aroma zbog kojih se i koriste u proizvodnji sokova (Miljković, 1991). $\mathrm{pH}$ - vrijednosti analiziranih sokova svih istraživanih sorti jabuka prikazani su $\mathrm{u}$ Tablici 1, a kreću se u rasponu od 3,55 ('Idared') do 4,04 ('Golden Delicious'). Sok dobiven iz plodova sorte 'Golden Delicious' ima najveću pH-vrijednost, nešto niže $\mathrm{pH}$ vrijednosti ima sok sorte 'Jonagold', 'Cripps Pink', dok je najniža $\mathrm{pH}$ vrijednost utvrđena u soku sorte 'Idared'. Uspoređujući rezultate ostalih autora $\mathrm{s}$ dobivenim rezultatima $\mathrm{pH}$ vrijednosti sokova jabuka $\mathrm{u}$ ovom istraživanju, vidljivo je da su pH-vrijednosti sokova sorti 'Idared' i 'Cripps Pink' (koje imaju slična sortna svojstva) približno jednake (3,55 i 3,59), dok sokovi sorti 'Jonagold' i 'Golden Delicious' (koje također imaju slična sortna svojstva) malo variraju iznad prosječnih vrijednosti navedenih za te sorte prema drugim literaturnim navodima (Brajanoski i Brajanoski, 2004.; Eisele i Drake, 2005.; Suarez i sur., 2011.; Illera i sur, 2019.). Temeljem relativno niskih $\mathrm{pH}$-vrijednosti soka utvrđene su visoke vrijednosti ukupnih kiselina (Tablica 1) $i$ to $u$ rasponu od 0,24\% ('Golden Delicious') do 0,53\% ('Cripps Pink'). Dobiveni rezultati sadržaja ukupnih kiselina (UK_KIS) u sokovima podudaraju se s literaturnim podacima (Eisele i Drake, 2005.). Statistička odstupanja sadržaja UK_KIS utvrđena su u sokovima sorata 'Jonagold' i 'Golden Delicious', a kao glavni razlog je taj što su navedene sorte općenito karakteristične po visokom sadržaju šećera i niskom sadržaju ukupnih kiselina (sortna karakteristika) (Brajanoski i Brajanoski, 2004.). Izmjerene vrijednosti za gustoću istraživanih sokova (Tablica 1) kretale su se u raspnu od $9,39\left(\mathrm{~g} / \mathrm{cm}^{3}\right)$ kod sorte 'Golden Delicious' do 13,43 $\left(\mathrm{g} / \mathrm{cm}^{3}\right)$ kod sorte'Jonagold'. Dobivene vrijednosti u ovom istraživanju u skladu su s podacima koje navode drugi istraživači u svojim istraživanjima (Brajanoski i Brajanoski, 2004.; Illera i sur, 2019.).

U Tablici 2 prikazan je sadržaj prirodnog, ukupnog inverta i saharoze u mutnim sokovima različitih sorata jabuke. Utvrđene su statistički značajne razlike u sadržaju prirodnog inverta između analiziranih uzoraka sokova, prilikom čega su se vrijednosti kretale u rasponu od 7,83\% u soku sorte 'Cripps Pink' do 9,41\% u soku sorte 'Idared'. Sorte 'Golden Delicious' i 'Jonagold' imale su ujednačenije iznose (8,51 \% i 8,80\%). Sadržaj ukupnog 
inverta također se značajno statistički razlikovao s obzirom na uzorak soka jabuke, a vrijednosti su bile u rasponu od 9,31\% za sok sorte 'Golden Delicious' do $16,06 \%$ za sok sorte 'Cripps Pink'. Sadržaj ukupnog inverta u soku sorte 'Idared' iznosio je 10,02\%, dok je za sok sorte 'Jonagold' iznosio 14,14\%. Statistički značajne razlike utvrđene su i za sadržaj saharoze ovisno o sorti soka. Manje vrijednosti utvrđene su u sokovima sorti 'Golden Delicious' i 'Idared' (0,76\% i 0,58\%), dok su u sokovima sorti 'Jonagold' i 'Cripps Pink' određene značajno veće vrijednosti (5,07\% i 7,82\%). Pri odabiru sirovine za proizvodnju soka osim sorte, jako je važno da su plodovi u fazi tehnološke zrelosti. Plodovi koji nisu adekvatnog stupnja zrelosti (ili nedozreli) ne sadrže dovoljnu količinu pojedinih nutritivnih komponenti karakterističnih za sortu, te sadrže manje količine jednostavnih šećera, a veće količine škroba pa se u konačnici od takvih plodova dobije manja količina i sok lošije kvalitete. Također, ako su plodovi prezreli nisu adekvatni za proizvodnju soka jer se dobije manja količina soka zbog otežanog istiskivanja jer jedan dio neotopljenih tvari prelazi u tekuću fazu. Vrlo često se taj problem javlja ako su plodovi jabuke bilu dugo skladišteni. $\mathrm{U}$ istraživanjima drugih autora navode se slične vrijednosti ugljikohidrata kao i u ovom istraživanju (Brajanoski i Brajanoski, 2004.).

Tablica 2. Sadržaj prirodnog, ukupnog inverta i saharoze sokova jabuke

Table 2 of Natural and total invert and sucrose content

\begin{tabular}{|c|c|c|c|}
\hline Uzorak & Prirodni invert (\%) & Ukupni invert (\%) & Saharoza (\%) \\
\hline & $\mathrm{p} \leq 0,0001$ & $\mathrm{p} \leq 0,0001$ & $\mathrm{p} \leq 0,0001$ \\
\hline S1 & $8,51 \mathrm{c} \pm 0,01$ & $9,31 \mathrm{~d} \pm 0,01$ & $0,76 \mathrm{c} \pm 0,01$ \\
\hline S2 & $9,41 \mathrm{a} \pm 0,01$ & $10,02 \mathrm{c} \pm 0,01$ & $0,58 \mathrm{~d} \pm 0,01$ \\
\hline S3 & $7,83 \mathrm{~d} \pm 0,01$ & $16,06 \mathrm{a} \pm 0,01$ & $7,82 \mathrm{a} \pm 0,01$ \\
\hline S4 & $8,80 \mathrm{~b} \pm 0,01$ & $14,14 \mathrm{~b} \pm 0,01$ & $5,07 \mathrm{~b} \pm 0,01$ \\
\hline
\end{tabular}

S1 - sok sorte 'Golden Delicious' ; S2- sok sorte 'Idared'; S3- sok sorte 'Cripps Pink'; S4 - sok sorte 'Jonagold'. Prikazane su prosječne vrijednosti \pm SD (standardna devijacija). Različita slova pridodana prosječnim vrijednostima označuju da se sorte statistički značajno razlikuju u istraživanom svojstvu prema $\mathrm{p} \leq 0,0001$.

Sadržaj vitamina C (mg/100 g svježeg ploda) u sokovima svih četiriju analiziranih sorti jabuka kreće se u rasponu od 4,91 do $6,75 \mathrm{mg} / 100 \mathrm{~g}$ svježeg ploda jabuke (Tablica 3). Najveći sadržaj vitamina C utvrđen je u soku sorte 'Jonagold' $(6,75 \mathrm{mg} / 100 \mathrm{~g}$ svježeg ploda), zatim u sokovima sorti 'Idared' i 'Cripps Pink' (6,13 i 6,44 mg/100 g svježeg ploda), dok je najmanji sadržaj utvrđen u soku sorte 'Golden Delicious' (4,91 mg/100 g svježeg ploda). $\mathrm{U}$ usporedbi s drugim literaturnim navodima, sadržaj vitamina $\mathrm{C}$ u istraživanim 
sokovima pokazuje znatno niži sadržaj u 100 g svježeg ploda (Suarez i sur., 2011.). Razlog navedenim odstupanjima u sadržaju vitamina $\mathrm{C} u$ sokovima analiziranim u ovom istraživanju i literaturnim navodima drugih autora može biti u vremenu skladištenja samih plodova jabuka. Naime, plodovi jabuka istraživanih sorti prije proizvodnje soka, skladišteni su u hladnjačama $u$ razdoblju od tri mjeseca što je moglo pogodovati degradaciji sadržaja vitamina C. Vitamin C podložan je značajnoj degradaciji sadržaja zbog utjecaja svijetla, povišene temperature, ali i duljini skladištenja neke sirovine (Suarez i sur., 2011.).

Sadržaj ukupnih fenola $u$ analiziranim sokovima različitih sorti jabuka (Tablica3) kretao se u rasponu od 18,44 mgGAE/100 g svježe tvari do 55,84 mgGAE/100 g svježe tvari. Najveći sadržaj ukupnih fenola utvrđen je u soku jabuke sorte 'Jonagold' (55,84 mgGAE/100 g svježe tvari), zatim u soku sorte 'Idared' (30,39 mgGAE/100 g svježe tvari), 'Golden Delicious' (20,66 mg GAE/100 g svježe tvari) i najmanja koncentracija ukupnih fenola utvrđena je u soku sorte 'Cripps Pink' (18,44 mgGAE/100 g svježe tvari). Sadržaj ukupnih neflavonoida kretao se u rasponu od 13,50 mgGAE/100 g svježe tvari kod sorte 'Cripps Pink' do 31,14 mgGAE/100 g svježe tvari kod sorte 'Jonagold'. Sadržaj ukupnih flavonoida kretao se u rasponu od 3,69 mgGAE/100 g svježe tvari kod sorte 'Golden Delicious' do $24,70 \mathrm{mgGAE} / 100 \mathrm{~g}$ svježe tvari kod sorte 'Jonagold'. S obzirom na literaturne navode drugih autora, rezultati sadržaja ukupnih fenola, flavonoida i neflavonoida utvrđeni ovim istraživanjem znatno su niži (Kahle i sur., 2005.; Hui i sur., 2006.; Oszmianski i sur., 2007.), što ponovno može biti posljedica skladištenja plodova jabuka kroz duži vremenski period. Naime, neadekvatni uvjeti skladištenja kao i relativno dugo vremensko razdoblje skladištenja plodova jabuka značajno utječu na redukciju svih fenolnih spojeva karakterističnih za voćnu vrstu jabuku (Gliszczynska-Swiglo i sur., 2003.; Mandal i sur. 2018.). Također, značajno je spomenuti i to da literaturni navodi naglašavaju kako mutni sok od jabuke sadržava i do četiri puta veću koncentraciju ukupnih fenolnih spojeva od bistrih sokova (Kahle i sur., 2005.; Oszmianski i sur, 2007.; Rodrigues i sur. 2017.), što mutnim sokovima daje veliku prednost u procesu proizvodnje i u konačnici nutritivnoj kvaliteti. 
Tablica 3. Bioaktivni spojevi sokova različitih sorti jabuka

Table 3 Bioactive compounds of juices of different apple varieties

\begin{tabular}{|c|c|c|c|c|}
\hline Uzorak & $\begin{array}{c}\text { VIT_C } \\
\text { (mg/100 g } \\
\text { svježe tvari) }\end{array}$ & $\begin{array}{c}\text { UK_FENOLI } \\
\text { (mgGAE/100 g } \\
\text { svježe tvari) }\end{array}$ & $\begin{array}{c}\text { NFLV } \\
\text { (mgGAE/100 g } \\
\text { svježe tvari) }\end{array}$ & $\begin{array}{c}\text { FLAV } \\
\text { (mgGAE/100 g } \\
\text { svježe tvari) }\end{array}$ \\
\hline & $\mathrm{p} \leq 0,0373$ & $\mathrm{p} \leq 0,0001$ & $\mathrm{p} \leq 0,0001$ & $\mathrm{p} \leq 0,0001$ \\
\hline $\mathrm{S} 1$ & $4,91 \mathrm{~b} \pm 1,06$ & $20,66 \mathrm{c} \pm 0,93$ & $16,98 \mathrm{c} \pm 0,51$ & $3,69 \mathrm{~b} \pm 0,55$ \\
\hline $\mathrm{S} 2$ & $6,13 \mathrm{a} \mathrm{b} \pm 0,53$ & $30,39 \mathrm{~b} \pm 1,67$ & $23,71 \mathrm{~b} \pm 0,49$ & $6,68 \mathrm{~b} \pm 1,28$ \\
\hline $\mathrm{S} 3$ & $6,44 \mathrm{a} \mathrm{b} \pm 0,01$ & $18,44 \mathrm{c} \pm 0,79$ & $13,50 \mathrm{~d} \pm 0,35$ & $4,94 \mathrm{~b} \pm 0,60$ \\
\hline $\mathrm{S} 4$ & $6,75 \mathrm{a} \pm 0,53$ & $55,84 \mathrm{a} \pm 4,29$ & $31,14 \mathrm{a} \pm 0,40$ & $24,70 \mathrm{a} \pm 3,93$ \\
\hline
\end{tabular}

S1 - sok sorte 'Golden Delicious'; S2- sok sorte 'Idared'; S3- sok sorte 'Cripps Pink'; S4 - sok sorte 'Jonagold'; VIT_C - sadržaj vitamina C; UK_FENOLI - sadržaj ukupnih fenola; NFLV - sadržaj ukupnih neflavonoida; FLAV - sadržaj ukupnih flavonoida. Prikazane su prosječne vrijednosti \pm SD (standardna devijacija). Različita slova pridodana prosječnim vrijednostima označuju da se sorte statistički značajno razlikuju u istraživanom svojstvu prema $\mathrm{p} \leq 0,0001$

\section{ZAKLJUČAK}

Ovim istraživanjem utvrđeno je da sorta 'Idared' s obzirom na mehanički sastav pokazuje najveći postotak iskoristivosti za dobivanje soka, dok sorta 'Cripps Pink' najmanji. Najveći postotak ukupnih kiselina zabilježen je u soku sorte 'Cripps Pink', a najmanji u soku sorte 'Golden Delicious' što navodi na zaključak da je postotak ukupnih kiselina veći u soku jabuka koje su karakteristične po kiselom okusu (sortna karakteristika), a manji kod sorata slatkastog okusa. Utvrđeno je da sokovi sorata 'Golden Delicious' i 'Jonagold' imaju najveći omjer topljive suhe tvari i ukupnih kiselina, odnosno sok navedenih sorti jabuka pokazuje najbolju harmoničnost okusa što je i za očekivati jer su to sorte izrazitih, osebujnih aroma. Također, nezanemariv kemijski parametar kvalitete nekog proizvoda je i sadržaj suhe tvari prilikom čega treba zaključiti kako sokovi svih analiziranih sorti pokazuju visoki postotak iste.

Relativno nizak sadržaj vitamina $\mathrm{C}$ i ukupnih fenola u mutnim sokovima svih analiziranih sorti jabuka posljedica je vremenskog perioda skladištenja plodova jabuka.

Temeljem dobivenih rezultata može se zaključiti da su plodovi svih istraživanih sorti pogodni za proizvodnju mutnog soka, ali i da mogu biti dobra podloga za proizvodnju ostalih sokova od raznih vrsta voća. 


\section{LITERATURA}

AOAC (1995.): Official methods of analysis (16th ed.). Washington, DC: Association of Official Analytical Chemists.

AOAC (2002.): Official methods of analysis (17th ed.). Washington, DC: Association of Official Analytical Chemists.

BRAJANOSKI, B., BRAJANOSKI, D. (2004.): Nove tehnologije u proizvodnji koncentrisanog soka jabuke. Procesna tehnika i energetika u poljoprivredi. 8 (3-4): 87-89.

EISELE, T. A., DRAKE, S. R. (2005.): The partial compositional characteristics of apple juice from 175 apple varieties. Journal of food composition and Analysis. 18: 213-221.

FARIA, W., KUMAR, B., RODRIGUEZ, Ó., SOUSA, E., BRITO, D., ANDRÉ, F., RODRIGUES, S. (2017.): Effect of ultrasound followed by high pressure processing on prebiotic cranberry juice. Food Chemistry. 218: 261-268.

FONTELES, T. V., RODRIGUES, S. (2018.): Prebiotic in fruit juice : Processing challenges, advances, and perspectives. Current Opinion in Food Science. 22: $55-61$.

GLISZCZYNSKA-SWIGLO, A., TYRAKOWSKA, B. (2003.): Quality of commercial apple juices evaluated on the basis of the polyphenol content and the TEAC antioxidant activity. Journal of Food Science. 68: 1844-1849.

HUI Y.H., BARTA J., PILAN CANO M., GUSEK T., SIDHU J.S., SINHA N.(2006.): Handbook of Fruits and Fruit Processing, Blackwell Publishing, Iowa, USA.

ILLERA, A. E., CHAPLE, S., SANZ, M. T., NG, S., LU, P., JONES, J., CAREY, E., BOURKE, P. (2019). Effect of cold plasma on polyphenol oxidase inactivation in cloudy apple juice and on the quality parameters of the juice during storage. Food Chemistry X 3 . https://doi.org/10.1016/j.fochx.2019.100049

KAHLE K., KRAUS M., RICHLING E. (2005.): Polyphenol profiles of apple juices. Molecular Nutrition \& Food Research. 49: 797-806.

KATALINIĆ V. (2006.): Kemija mediteranskog voća i tehnologija prerade. skripta I. dio. Kemijsko tehnološki fakultet. Split. 
KAUR, C., KAPOOR, C.H. (2001.): Antioxidants in fruits and vegetables - the millennium's health. International Journal of Food Science and Technology. 36 (7): 703-725.

KOTAR, F., LUČIĆ, D., SKALNIK, B., SKALNIK, D. (2009.): Tehnologija prerade jabuka u sokove od jabuka. https:/www.agroklub.com/vocarstvo/ sok-od-jabuke/780/

KRPINA, I., VRBANEK, J., ASIĆ, A., LJUBIČIĆ, M., IVKOVIĆ, F., ĆOSIĆ, T., ŠTAMBUK, S., KOVAČEVIĆ, I., PERICA, S., NIKOLAC, N., ZEMAN, I., ZRINŠĆAK, V., CVRLJE, M., JANKOVIĆ- ČOKO, D. (2004.): Voćarstvo. Nakladni zavod Globus. Zagreb.

MANDAL, R., SINGH, A., \& SINGH, A. P. (2018.): Recent developments in cold plasma decontamination technology in the food industry. Trends in Food Science \& Technology. 80: 93-103.

MILJKOVIĆ I. (1991.): Suvremeno voćarstvo. Znanje. Zagreb.

NIKETIĆ-ALEKSIĆ, G. (1988.): Tehnologija voća i povrća. Naučna knjiga. Beograd.

OSZMIANSKI, J., WOLNIAK, M., WOJDYLO, A., WAWER, I. (2007.): Comparative study of polyphenolic content and antiradical activity of cloudy and clear apple juices. Journal of the Science of Food and Agriculture. 87: 573-579.

OUGH, C. S., AMERINE, M. A. (1988.): Methods for Analysis of Musts and Wines. John Wiley and Sons. New York. USA

RODRÍGUEZ, Ó., GOMES, W .F., RODRIGUES, S., FERNANDES, F. A. N.(2017.): Effectofindirect cold plasma treatment on cashew apple juice (Anacardium occidentale L.). LWT Food Science and Technology. 84: 457-463.

RODRÍGUEZ DE-BERNALDO QUIRÓS, A., FERNÁNDEZ-ARIAS, M., LÓPEZ HERNÁNDEZ, J (2006.): Screening method for the determination of ascorbic acid in fruit juices and soft drinks. Food Chemistry. 116 (2): 509-512.

SAS/STAT (2010.): SAS Institute. Cary. NC. USA.

SUÁREZ-JACOBO, A., RÜFER, C. E., GERVILLA, R., GUAMIS, B., ROIGSAGUÉS, A. X., SALDO, J. (2011.): Influence of ultra-high pressure homogenisation on antioxidant capacity polyphenol and vitamin content of clear apple juice. Food Chemistry. 127: 447-454. 


\section{Adresa autora - Authors address:}

Sandra Voća,

Jana Šic Žlabur, e-mail: jszlabur@agr.hr

Martina Skendrović Babojelić,

Ante Galić

Mislav Boić, Diplomski studij, Hortikultura

Agronomski fakultet Zagreb, Sveučilište u Zagrebu, Svetošimunska cesta 25, 10000 Zagreb 
